\title{
The Entrepreneurial Orientation of STMIK STIKOM Indonesia's Students
}

\author{
Wayan Eny Mariani ${ }^{1}$, Ni Putu Ayu Siska Wulantari² \\ \{wayanenymariani@gmail.com¹, siskawulantari18@gmail.com² ${ }^{2}$,
}

STMIK STIKOM Indonesia, Jalan Tukad Pakerisan no. 97, Denpasar ${ }^{1,2}$

\begin{abstract}
Increased unemployment in Indonesia due to Covid-19 pandemic causes people to have to start changing mindsets to try to become an entrepreneur. Entrepreneurship will help the government in reducing unemployment. It is important to grow the entrepreneurial mentality of the younger generation so that they have the mindset to create their own employment opportunities. Fostering an entrepreneurial mentality can be done at the level of higher education. STMIK STIKOM Indonesia is a college that encourages students to enter the business world. This study aims to identify the entrepreneurial orientation of STMIK STIKOM Indonesia students so that it can be used as a basis for determining other supporting activities that need to be carried out in order to develop the entrepreneurial spirit of STMIK STIKOM Indonesia students. The approach of this study is using quantitative method by a questionnaire. The population of this study is all STMIK STIKOM Indonesia's students who already pass Entrepreneurship courses. Purposive sampling method is used to conduct the sample for this study. The research found that STMIK STIKOM Indonesia students who had taken entrepreneurship courses had a high entrepreneurial orientation.
\end{abstract}

Keywords: Entrepreneurial Orientation, Entrepreneurship, Entrepreneur Characteristic.

\section{Introduction}

In the Covid-19 pandemic situation so many companies went bankrupt. According to Bloomberg notes, since the beginning of March 2020 there were 133 companies in the US that filed for bankruptcy protection because of Covid-19. CNBC reported that 30 percent of restaurants in the US were threatened with bankruptcy and were permanently closed due to Covid-19, even though the US Government provided soft loans to pay employees. NPC International, the largest Pizza Hut franchiser in the US filed for bankruptcy on July 1. S\&P Global Ratings said Starbucks could go bankrupt this year, even though the chances are small, under 10 percent [1]. Various companies in Indonesia also experienced the same impact due to this pandemic. Some of the things the company did in response to the impact of this pandemic were temporary termination of service or outlets, salary cuts, termination of employment, or permanent termination of operations. Several companies or businesses in Indonesia affected by the corona virus and decided to close or layoff at their businesses, namely Traveloka, Ramayana, KFC, STOQO, Airy, and Airbnb [2]. This of course resulted in an increase of the world unemployment rate and particularly in Indonesia.

Increased unemployment in Indonesia causes people to have to start changing mindsets to try to become an entrepreneur. Entrepreneurs are people who, in any event, are still able to stand on their own ability to help themselves out of the difficulties they face, including overcoming poverty without anyone's help [3]. Entrepreneurship intention has been extensively study by researchers in economics, management, sociology, psychology, as well 
as in anthropology due to its importance to the development of an economy by way of job creation and wealth creation[4]. Entrepreneurship will help the government in reducing unemployment and also provide opportunities for people to be able to create their own income. It is important for the younger generation to have the ability to help them get out of the difficulties they face and then help others by opening up employment opportunities for themselves and the wider community [5]. Entrepreneurship is one of the key elements that will lead to a successful business performance under highly uncertain business conditions[6]. It is important to grow the entrepreneurial mentality of the younger generation so that they have the mindset to create their own employment opportunities compared to only working at existing companies. Entrepreneurship is synonymous with the risks that must be faced in running a business. Lack of knowledge about how to deal with risk or how to run a business effectively and efficiently can lead to failure in entrepreneurship. This can be anticipated by deepening the insight and entrepreneurial skills early on.

Fostering an entrepreneurial mentality and broadening insights about entrepreneurship can be done at the level of higher education. Higher education as an educational institution that is obliged to create a qualified human resources to be useful for society at large has a great opportunity to foster entrepreneurial spirit and provide insight about entrepreneurship to its students. Based on the empirical study of 17 country students, participants in entrepreneurship education showed higher entrepreneurial intentions[7]. STMIK STIKOM Indonesia is a college that encourages students to enter the business world. The thing done by STMIK STIKOM Indonesia in an effort to foster entrepreneurial spirit for its students is to include entrepreneurship courses in the curriculum of each study program. In addition, STMIK STIKOM Indonesia also has a STIKI Indonesia Business Incubator which is a forum for the STMIK STIKOM Indonesia academic community to get to know more about entrepreneurship. This study aims to identify the entrepreneurial orientation of STMIK STIKOM Indonesia students so that it can be used as a basis for determining other supporting activities that need to be carried out in order to develop the entrepreneurial spirit of STMIK STIKOM Indonesia students.

\section{Entrepreneurial Concept}

Entrepreneurship is a person or group of people who spend a certain amount of money to buy a number of goods, then the goods are displayed in a certain location for resale to consumers. Or a person buys a number of goods and then they are processed or processed and then served in the form of food in a location for the consumer to enjoy. Or someone buys various raw materials, is processed and processed into certain goods and then traded to various areas that are in need[8]. Entrepreneurship is the spirit, attitude, behavior and ability of a person in handling a business and or activity that leads to efforts to find, create, implement new work methods, technology and production by increasing efficiency in order to provide better service and /or obtain greater benefits[9]. Understanding of what make an individual to become an entrepreneur is important in developing new entrepreneurs. This is due to the fact that entrepreneurship is a complex process that involves entrepreneurial cognition and entrepreneurial actions[10].

Entrepreneurial competence is needed to be a successful entrepreneur. To be a successful entrepreneur, a person need to have knowledge, skills, attitudes and motivation about business. Entrepreneurial competence is a fundamental characteristic of an individual in creating creative and innovative opportunities or opportunities. The criteria for an entrepreneur are creative and innovative, the ability to gather resources, turn opportunities into profits under conditions of risk and uncertainty[11]. 
How a person think and behave influence their intention to become an entrepreneur[12]. Entrepreneurial orientation is the tendency of individuals to innovate, be proactive and willing to take risks to start or manage a business[13].

1. Innovating. Innovating means always trying to improve efficiency, effectiveness and productivity in every aspect of business activities, and increasing vigilance in the face of business competition.

2. Proactiveness. Proactiveness means always having initiative and not waiting, and thinking in a visionary way so that you have a planning that is not only short-term, but long-term (strategic), and learns from other people's experiences, failures, and can be open to receiving criticism and suggestions for input on business development.

3. Managing Risks. Dare to take risks, and adjust risk profiles and know the risks and benefits of a business. A company must have risk management in all their business activities.

\section{Method}

The approach taken in this research is descriptive. The purpose of this study was to determine the entrepreneurial orientation of STMIK STIKOM Indonesia students. This research uses a quantitative method with an instrument in the form of a questionnaire distributed to students of STMIK STIKOM Indonesia. The indicators used in the questionnaire consisted of questions relating to the respondent's entrepreneurial orientation. The questions related to entrepreneurial orientation variables include student character related to the attitude of innovating, proactiveness, and managing risks. The measurement scale used in this study is a Likert scale. Then the research data was collected. Population is the sum of all elements or members of the population studied[14]. The population of this research is STMIK STIKOM Indonesia students. This study does not use all members of the population so it is sufficient to take some of the members of the population who are representative or known as research samples. Data collection techniques were carried out using purposive sampling method with the criteria of students who have received entrepreneurship courses. Literature study is done as a basis for problem solving and compilation of questions for data collection in the field. Data analysis was carried out on the results of questionnaires from respondents which would be summarized in tabular form to make it easier to draw conclusions.

\section{Results And Discussions}

\subsection{Entrepreneurial Orientation}

Entrepreneurial orientation is state as an individual's tendency to innovate, be proactive and be willing to take risks to start or manage a business[13]. Various literatures describe entrepreneurial orientation as follows:

1. Innovating. It means always trying to increase efficiency, effectiveness and productivity in every aspect of SME activities, and increase vigilance in facing business competition[13]. Innovation influences small business entrepreneurship[15]. 
2. Proactiveness. It means always having initiative and not waiting, and thinking visionary so that planning is not only short-term, but is long-term (strategic), and learns from other people's experiences, failures, and can openly accept criticism and suggestions for SME development input[13].

3. Managing Risks. Dare to take risks, and adjust risk profiles and know the risks and benefits of a business. SMEs must have risk management in all business activities[13].

\subsection{Statistic Descriptive}

The samples are STMIK STIKOM Indonesia's students who've been studied Entrepreneurship courses. There are 238 respondents who respond the questionnaire. The questionnaire consist of nine questions which belong to three sub variables of entrepreneurial orientation.

Table 1. Calculation of Entrepreneurial Orientation Variable Scores

\begin{tabular}{|c|c|c|c|c|c|c|c|}
\hline Item & 2 & 3 & 4 & Total & Total Score & Ideal Score & Persentage \\
\hline 1 & 6 & 149 & 83 & 238 & 791 & 952 & $83.09 \%$ \\
\hline 2 & 21 & 134 & 83 & 238 & 776 & 952 & $81.51 \%$ \\
\hline 3 & 7 & 157 & 74 & 238 & 781 & 952 & $82.04 \%$ \\
\hline \multicolumn{4}{|c|}{$\begin{array}{l}\text { Persentage } \\
\text { Innovating }\end{array}$} & \multicolumn{4}{|l|}{$82.21 \%$} \\
\hline 4 & 1 & 153 & 78 & 238 & 784 & 952 & $82.35 \%$ \\
\hline 5 & 59 & 141 & 37 & 238 & 690 & 952 & $72.48 \%$ \\
\hline 6 & $\begin{array}{ll}0 & 12 \\
\end{array}$ & 162 & 64 & 238 & 766 & 952 & $80.46 \%$ \\
\hline \multicolumn{4}{|c|}{$\begin{array}{l}\text { Persentage of Sub Variable } \\
\text { Proactiveness }\end{array}$} & \multicolumn{4}{|l|}{$78.43 \%$} \\
\hline 7 & $\begin{array}{ll}0 & 37\end{array}$ & 170 & 31 & 238 & 708 & 952 & $74.37 \%$ \\
\hline 8 & 30 & 168 & 40 & 238 & 724 & 952 & $76.05 \%$ \\
\hline 9 & 18 & 159 & 61 & 238 & 757 & 952 & $79.52 \%$ \\
\hline \multicolumn{4}{|c|}{$\begin{array}{l}\text { Persentage of Sub Variable } \\
\text { Managing Risk }\end{array}$} & $76.65 \%$ & & & \\
\hline
\end{tabular}

According to the table, the highest score of entrepreneurial orientation's sub variables is innovating. The lowest score of entrepreneurial orientation's sub variables is managing risk.

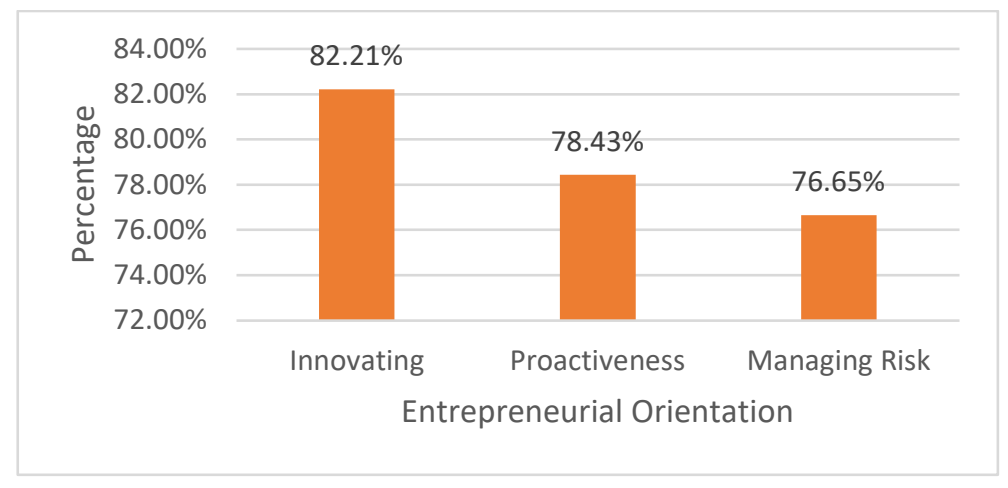

Fig.1. Entrepreneurial Orientation of STMIK STIKOM Indonesia's Students 
Based on Figure 1. Entrepreneurial orientation sub variable which has the highest value is an innovating sub variable with a value of $82.21 \%$. Entrepreneurial orientation sub variable which has the lowest value is managing risk with a value of $76.65 \%$. The results of the questionnaire showed that STMIK STIKOM Indonesia students who had taken entrepreneurship courses had a high entrepreneurial orientation with an average of $79.10 \%$. This shows that STMIK STIKOM Indonesia students have the qualities needed to become an entrepreneur.

\subsection{Data Analysis Result}

Based on the results of the questionnaire STMIK STIKOM Indonesia's students have a high entrepreneurial orientation. The highest entrepreneurial orientation of STMIK STIKOM Indonesia's students is innovating. Innovation is the willingness to introduce newest and novelty through a process of experimentation and creativity aimed at developing new products and services or new processes[16]. These findings mean that STMIK STIKOM Indonesia students like to create or find something new. They like to be a trend setter than just be a follower. They also prefer to work effectively in the most efficient way. They are likely gain any new information about anything in their interest.

Proactiveness is a prospective forward-looking characteristic that has a foresight look for opportunities to anticipate future requests[16]. Proactiveness means they are more likely to start and finish the work, they are enjoying working together as a teams and they have willingness to ask more if they don't understand any subject in the discussion. Proactive personality and innovative means an entrepreneur has to be aware of any changing which can influence their business. This will for the entrepreneur to gain each information related o their business and finding any new idea for their business sustainability[17]. Managing risk is the willingness of companies to decide and act without definite knowledge of possible earnings and possibly speculate in personal, financial and business risks[16]. Managing risk means how a particular person react to particular situation which they have no idea about and how they handle it. Managing risk means they don't mind taking risks that will give the right results. They understand that there are realistic risk in aiming something.

SMEs are able to survive in business competition if they have entrepreneurial behaviors such as being active or able to quickly respond to threats and take advantage of available market opportunities. Then, dare to take risks for business opportunities. Finally, continue to innovate the products and services provided to its customers. Because of that, entrepreneurial behavior (proactivity, risky courage, and innovation) is what influences company performance[18]. An entrepreneurially oriented company has better performance than a company which not adopting an entrepreneurial orientation[19].

That means if a company want to keep their business sustainable they have to had this three of entrepreneurial orientation. Effective entrepreneurial intention among students highly depend on entrepreneurial skill of the students [20].

STMIK STIKOM Indonesia's students already have this entrepreneurial orientation that means they have an opportunity to be an entrepreneur who can keep their business sustainability. Institutions rules, attitude, and social function plays a dominant role for university students to embark on an entrepreneurial career [21]. 


\section{Conclusions}

Based on the results of analysis and calculations conducted by researchers using analysis descriptive it can be concluded that STMIK STIKOM Indonesia students who had taken entrepreneurship courses had a high entrepreneurial orientation with an average of $79.10 \%$. These findings indicate that STMIK STIKOM Indonesia students have the opportunity to become a successful entrepreneur.

\section{Acknowledgments}

This research was supported by Kemenristek Dikti, STMIK STIKOM Indonesia and Universitas Muhammadiyah Purwokerto. We are thankful to Lembaga Penelitian dan Pengabdian Masyarakat STMIK STIKOM Indonesia who provided each information and facilities that greatly assisted the research. We thank all of our colleagues who supported this research.

\section{References}

[1] https://www.beritasatu.com/ekonomi/656907-20-perusahaan-terbesar-yang-terancam-bangkrut-di2020

[2] Vina Fadhrotul Mukaromah "Airy Tutup, Ini Daftar 6 Perusahaan yang PHK Karyawan karena Corona ", https://www.kompas.com.

[3] Alma, Buchari. 2010. Kewirausahaan (edisi revisi). Bandung: CV Alfabeta.

[4] Samuel, Y. A., Ernest, K., \& Awuah, J. B. (2013). An Assessment of Entrepreneurship Intention Among Sunyani Polytechnic Marketing Students. International Review of Management and Marketing, 3, 37-49.

[5] W. E. Mariani, "ENTREPRENEURSHIP INTEREST OF STMIK STIKOM INDONESIA'S STUDENTS", Jibeka, Vol. 13, No. 2, Pp. 71-78, Aug. 2019.

[6] Cho, Y.H. And Lee, J.-H. (2018), "Entrepreneurial Orientation, Entrepreneurial Education And Performance", Asia Pacific Journal Of Innovation And Entrepreneurship, Vol. 12 No. 2, Pp. 124134. Https://Doi.Org/10.1108/APJIE-05-2018-0028.

[7] Kuttim, M., Kallaste, M., Venesaar, U. And Kiis, A. (2014), "Entrepreneurship Education At University Level And Students' Entrepreneurial Intentions", Procedia-Social And Behavioral Sciences, Vol. 110, Pp. 658-668.

[8] Kasmir. 2011. Kewirausahaan, Edisi Revisi 6. Jakarta: Rajawali Persada.

[9] Suherman, Eman. 2010. Desain Pembelajaran Kewirausahaan. Bandung: Alfabeta.

[10] Hisrich, R. D., Peters, M. P., \& Shepherd, D. A. (2013). Entrepreneurship (9th Ed.). New York: Mcgraw Hill

[11] Dollinger, M. J. (2003). Entrepreneurship: Strategic And Resources (3rd Ed). New Jersey: Prentice Hall.

[12] Zain, Z.M., Akram, A.M., Ghani, E.K. (2010). Entrepreneurial Intention Among Malaysian Business Students. Canadian Social Science, 6(3), 34-44.

[13] Vitale R, Giglierano J, And Miles M, 2003, Entrepreneurial Orientation, Market Orientation, And Performance In Established And Startup Firms, Http://Www.Uic.Edu/Cba/Ies/2003papers.

[14] Cooper, P. S. \& Schindler, P. S. (2011). Business Research Methods. 11th Edition. Mcgraw-Hill.

[15] Hadiyati E. 2014. Karakteristik Kewirausahaan Dan Perusahaan Serta Kompentesi Kewirausahaan Sebagai Penentu Kinerja Usaha Kecil Menengah (UKM). Jurnal Ekonomika Bisnis. 5(2):117-124. 
[16] Lumpkin, G.T., \& Dess, G.G. (1996). Clarifying Entrepreneurial Orientation Construct And Linking It To Performance. Academy Of Management Review, 97(1), 135-72.

[17] Mariani, W.E. \& Anom, I.G.A, “The Characteristic Of Inkubator Bisnis STIKI Indonesia's Tenant” Proceeding Of The 3rd International Conference Of Research Education Administration And Management (ICREAM) 2019. Https://Www.Atlantis-Press.Com/Proceedings/Icream$19 / 125933821$.

[18] Wardi, Y., Susanto, P., Abdullah, N.L., "Orientasi Kewirausahaan Pada Kinerja Usaha Kecil Dan Menengah (UKM) Sumatera Barat: Analisis Peran Moderasi Dari Intensitas Persaingan, Turbulensi Pasar Dan Teknologi” Jurnal Manajemen Teknologi, 16(1), 2017, 46-61.

[19] Rauch A., Wiklund, J., Lumpkin, G.T., \& Frese, M. (2009). Entrepreneurial Orientation And Business Performance: An Assessment Of Past Research And Suggestion For The Future. Entrepreneurship Theory And Practice, (5), 761- 786.

[20] Sookhtanlo, M., Rezvanfar, A., Hashemi, S. M., \& Karaj, I. (2009). Psychological Capabilities Affecting Agricultural Students' Entrepreneurship Level: A Comparative Study. Research Journal Of Agriculture And Biological Sciences, 5, 175-184.

[21] Veciana, J. M., Aponte, M., \& Urbano, D. (2005). University Students' Attitudes Towards Entrepreneurship: A Two Countries Comparison. The International Entrepreneurship And Management Journal, 1, 165-182. 